SJîñn Jurnal

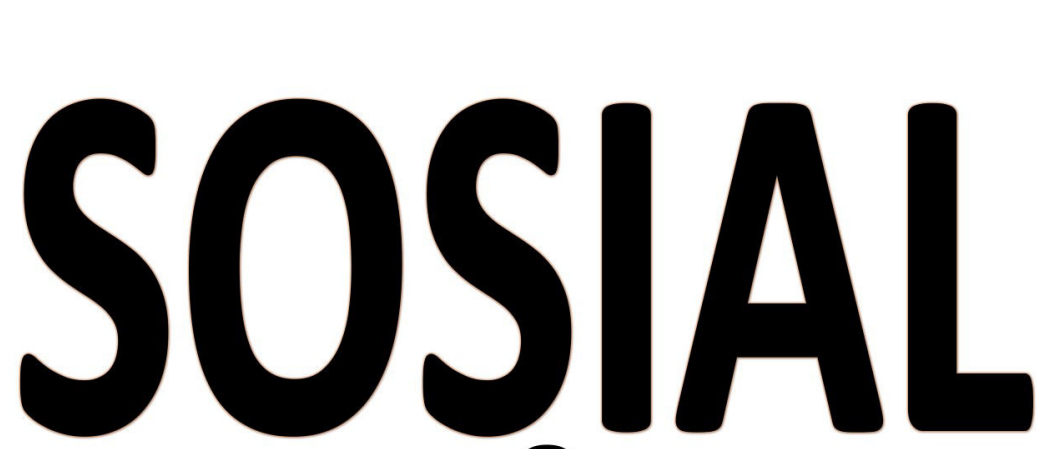

P-ISSN: 2356-1459 E-ISSN: 2654-9050 Vol. 7 No. 3 (2020)
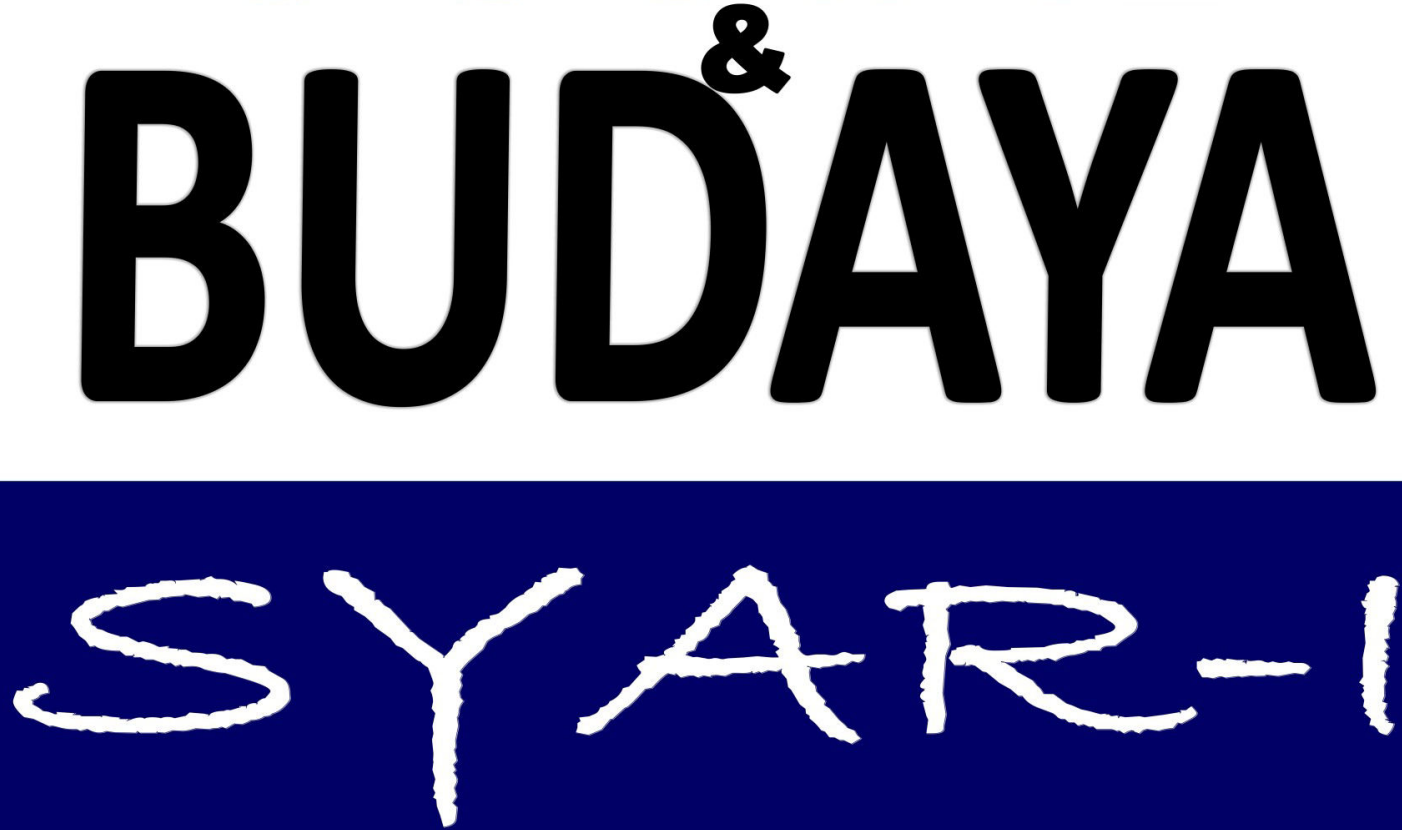

Konsep Tafakkur Dalam Alquran Dalam Menyikapi Coronavirus Covid-19 Indriya

Analisis Perilaku Masyarakat Indonesia dalam Menghadapi Pandemi Virus Corona (Covid-19) dan-

Kiat Menjaga Kesejahteraan Jiwa

Dana Riksa Buana

Kebijakan Pemberlakuan Lock Down Sebagai Antisipasi Penyebaran Corona Virus Covid-19

Nur Rohim Yunus, Annissa Rezki

Kebijakan Nabi Muhammad Saw Menangani Wabah Penyakit Menular dan Implementasinya dalam-

Konteks Menanggulangi Coronavirus Covid-19

Mukharom, Havis Aravik

Langkah Taktis Pemerintah Daerah Dalam Pencegahan Penyebaran Virus Corona Covid-19 di Indonesia Zahrotunnimah

Penggunaan Masker Penutup Wajah Saat Salat Sebagai Langkah Pencegahan Wabah Coronavirus Covid-19 Syandri, Fadhlan Akbar

Impact of Corona Virus Outbreak Towards Teaching and Learning Activities in Indonesia

Zaharah, Galia Ildusovna Kirilova, Anissa Windarti 


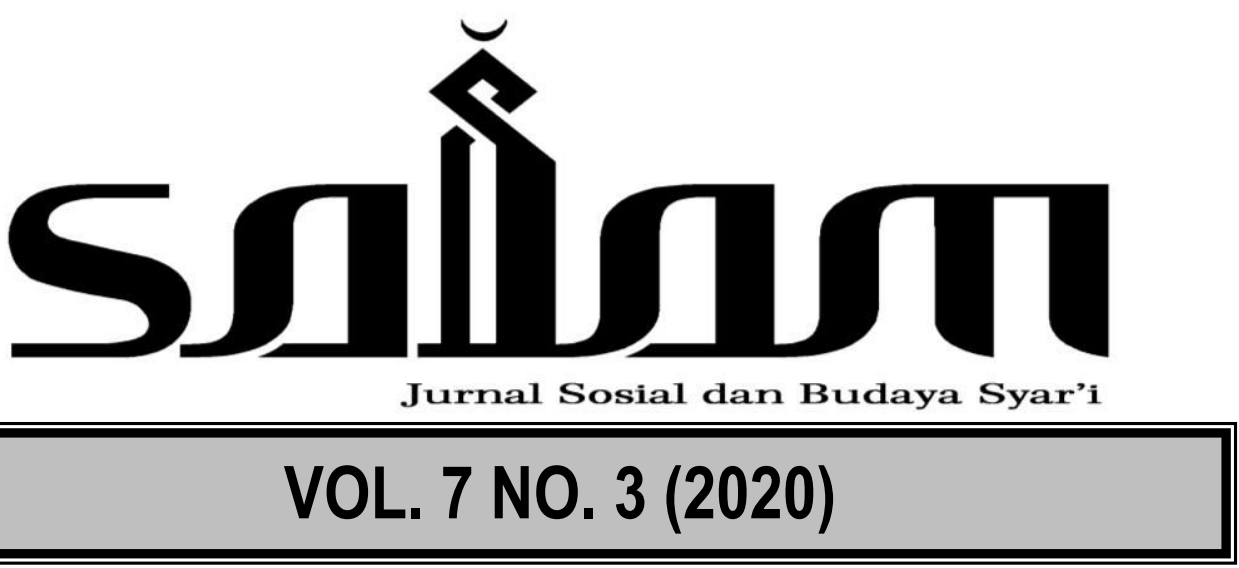

Diterbitkan oleh Fakultas Syariah dan Hukum Universitas Islam Negeri (UIN) Syarif Hidayatullah Jakarta.

Salam; Jurnal Sosial dan Budaya Syar-i mengkhususkan diri dalam pengkajian ilmu-ilmu Sosial dan Budaya dalam dimensi Syariah.

Terbit tiga kali dalam satu tahun di setiap bulan April, Agustus, dan Desember.

\section{Redaktur Ahli}

Muhammad Amin Suma (UIN Syarif Hidayatullah Jakarta) A Salman Maggalatung (UIN Syarif Hidayatull ah Jakarta) Asep Saepudin Jahar (UIN Syarif Hidayatullah Jakarta) Ahmad Mukri Aji (UIN Syarif Hidayatullah Jakarta) JM Muslimin (UIN Syarif Hidayatullah Jakarta) Muhammad Munir (IIU Islamabad Pakistan)

Euis Amalia (UIN Syarif Hidayatullah Jakarta)

Tim Lindsey (Melbourne University Australia)

Raihanah Azahari (University Malaya Malaysia)

Ahmad Tholabi (UIN Syarif Hidayatullah Jakarta)

Ahmad Hidayat Buang (University Malaya Malaysia)

\section{Pemimpin Redaksi \\ Erwin Hikmatiar}

\section{Sekretaris Redaksi}

Muhammad Ishar Helmi

Redaktur Pelaksana

Mara Sutan Rambe

Indra Rahmatullah

Nur Rohim Yunus

\section{Tata Usaha}

Imas Novita Juaningsih

Azizah Ratu Buana

\section{Alamat Redaksi}

Fakultas Syariah dan Hukum UIN Syarif Hidayatullah Jakarta Jl. Ir. H. Juanda 95 Ciputat Jakarta 15412 Telp. (62-21) 74711537, Faks. (62-21) 7491821

Website: www.fsh-uinjkt.net, E-mail: jurnal.salam@uinjkt.ac.id

Permalink: http://journal.uinjkt.ac.id/index.php/salam 


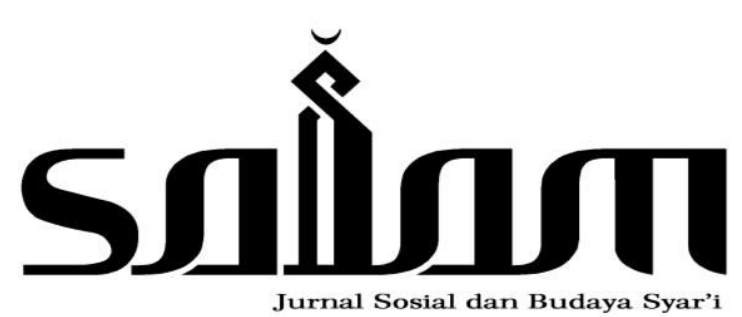

Menyambut baik kontribusi dari para ilmuwan, sarjana, profesional, dan peneliti dalam disiplin ilmu hukum untuk dipublikasi dan disebarluaskan setelah melalui mekanisme seleksi naskah, telaah mitra bebestari, dan proses penyuntingan yang ketat. 


\section{DAFTAR ISI}

\section{1-216}

Konsep Tafakkur Dalam Alquran Dalam Menyikapi Coronavirus Covid-19 Indriya

\section{7-226}

Analisis Perilaku Masyarakat Indonesia dalam Menghadapi Pandemi Virus Corona (Covid-19) dan Kiat Menjaga Kesejahteraan Jiwa

Dana Riksa Buana

\section{7-238}

Kebijakan Pemberlakuan Lock Down Sebagai Antisipasi Penyebaran Corona Virus Covid-19

Nur Rohim Yunus, Annissa Rezki

\section{9-246}

Kebijakan Nabi Muhammad Saw Menangani Wabah Penyakit Menular dan Implementasinya dalam Konteks Menanggulangi Coronavirus Covid-19 Mukharom, Havis Aravik

\section{7-260}

Langkah Taktis Pemerintah Daerah Dalam Pencegahan Penyebaran Virus Corona Covid-19 di Indonesia

Zahrotunnimah

\section{1-268}

Penggunaan Masker Penutup Wajah Saat Salat Sebagai Langkah Pencegahan Wabah Coronavirus Covid-19

Syandri, Fadhlan Akbar

\section{9-282}

Impact of Corona Virus Outbreak Towards Teaching and Learning Activities in Indonesia

Zaharah, Galia Ildusovna Kirilova, Anissa Windarti 



\title{
Impact of Corona Virus Outbreak Towards Teaching and Learning Activities in Indonesia*
}

\author{
Zaharah, ${ }^{1}$ Galia Ildusovna Kirilova ${ }^{2}$ Anissa Windarti ${ }^{3}$ \\ 13 Syarif Hidayatullah State Islamic University, Jakarta, \\ ${ }^{2}$ Kazan Federal University, Russia \\ 10.15408/sjsbs.v7i3.15104
}

\begin{abstract}
Lately, the world community was shocked by the Coronavirus outbreak that originated in the city of Wuhan, China that occurred in November 2019 last year. Coronavirus is very dangerous because until now no cure or vaccine has been found. Coronavirus attacks the human respiratory tract quickly. Transmission of this virus through, airborne and air to fellow humans. Its spread is very fast and cross-continent, WHO determined the spread of this virus over the plague and endemic, most of the countries registered at the UN contracted this virus, including Indonesia. This article aims to explain the impact of the coronavirus on teaching and learning activities, which so far teaching and learning processes are held in schools or classes but with the co-19 pandemics, teaching and learning activity is moved at home by E-Learning using various technological devices, such as smartphones, computers, and notebooks. The impact caused by the coronavirus involves various aspects, such as social, cultural, and worse, economic aspects. This study is carried out through a literature study by looking at the results of surveys and studies of literature, journals, and documents of several prints and electronic media and books relating to teaching and social society, sociology and anthropology. The conclusion of this paper shows the government's step in issuing policies to the public not to do any activities outside the home, all work is carried out from home, including teaching and learning activities.
\end{abstract}

Keywords: Impact, Plague, Virus corona, Teaching, and Learning Activities

\begin{abstract}
Abstrack
Akhir-akhir ini masyarakat dunia digemparkan oleh terjadinya wabah Coronavirus yang berasal dari kota Wuhan, China yang terjadi di bulan November 2019 tahun lalu. Corona virus ini sangat berbahaya karena sampai saat ini belum ditemukan obat atau vaksin penanggulangannya. Coronavirus menyerang saluran pernapasan manusia dengan cepat. Penularan virus ini melalui, airborne dan udara kepada sesama manusia. Penyebarannya yang sangat cepat dan lintas benua, WHO menetapkan penyebaran virus ini diatas wabah dan endemic, sebahagian besar negara yang terdaftar di PBB terjangkit virus ini, termasuk juga Indonesia.Artikel ini bertujuan untuk menjelaskan dampak dari virus corona
\end{abstract}

\footnotetext{
* Received: February 29, 2020, Revised: March 6, 2020, Published April 2020.

${ }^{1}$ Zaharah is a lecturer at the Tarbiyah Faculty of Science, Syarif Hidayatullah State Islamic University, Jakarta. Email: zaharah@uinjkt.ac.id.

${ }^{2}$ Galia Ildusovna Kirilova is a Lecturer in the Faculty of education and psychology. Kazan Federal University, Russia. Email: gikirilova@mail.ru

${ }^{3}$ Anissa Windarti is a lecturer at the Tarbiyah Faculty of Science, Syarif Hidayatullah State Islamic University, Jakarta. Email: anissa.windarti@uinjkt.ac.id
} 


\begin{abstract}
terhadap kegiatan belajar mengajar, yang selama ini proses belajar mengajar diadakan di sekolah atau kelas tetapi dengan adanya pendemi covid-19, KBM dipindahkan di rumah secara E-Learning dengan mengunakan berbagai alat technologi, seperti smartphone, komputer dan notebook. Dampak yang disebabkan oleh virus corona ini menyangkut perbagai aspek, seperti aspek sosial, budaya, dan yang lebih parah adalah aspek ekonomi. Kajian ini dilakukan melalui studi pustaka dengan melihat hasil-hasil survei dan studi literatur, journal dan document beberapa media cetak maupun elektronik serta buku yang berhubungan dengan pengajaran dan sosial masyrakat, sosiologi dan antropologi. Kesimpulan dari tulisan ini menunjukkan adanya langkah pemerintah mengeluarkan kebijakan kepada masyarakat untuk tidak beraktivitas apapun diluar rumah, semua pekerjaan dilaksanakan dari rumah, termasuk kegiatan belajar dan mengajar (KBM.
\end{abstract}

Keyword: Dampak, Wabah, Viruscorona, Kegiatan Belajar Mengajar

\title{
Introduction
}

Beginning in 2020 we were shocked by a new virus called Corona Virus or the term (COVID-19) virus that attacks the human respiratory system, which initially struck China, which was discovered in November 2019 precisely in the city of Wuhan. Coronavirus was originally considered a normal virus that comes and goes, it turns out that the prediction is wrong this virus is a virus other than the others that can kill humans and spread very quickly, with symptoms that resemble flu, colds, start coughing fever and runny nose or nose disorders. Until now there is no known cause of the Coronavirus, but it is known that this virus is spread by animals and is capable of transmitting from one species to another, including humans.

This incident is increasingly widespread in Wuhan society; many victims have fallen. Not only in the Wuhan community, but it has spread to other provinces in China. This situation was devastated for China which suffered a lot of economic losses, in addition to stopping all activities that normally run conducive. This virus is extraordinary, only in the last 3 months, this virus has claimed thousands of lives, even now it is not only in China that has the highest level of outbreaks but has overtaken other countries such as Italy, Iran, and South Korea, and followed other countries, such as Indonesia, Britain, Japan, the United States, Germany, and other countries.

In Indonesia, the government issued and provided several policies regarding the COVID-19 outbreak. One of them is the prohibition of people gathering and doing activities outside the home, and advocating to stay at home "Stay at Home, worship at home, work from home, learn from home." This is because this virus can be infected through physical contact, namely touch, air and airborne and must maintain social distance (physical distancing) of approximately 1.5 meters

One of the government's instructions about activities or activities at home is learning activities. Learning should not stop even if the government instructs 14 days off for schools and campuses in Indonesia. Teaching and learning activities (KBM) are moved at home, but must still be controlled by the teacher or lecturer and parents, using distance learning. This Distance Learning is carried out for approximately 14 days, but it does not rule out the possibility to be added again because of seeing the situation and conditions of this COVID-19 development. 


\section{Research methods}

This study uses a qualitative method with the study of literature (documents) from several sources both print and electronic media, as well as books and e-journals. Journal searches are carried out through Google Scholar. Based on the search results obtained and selected data that meets the criteria. Analysis of the literature review includes data collection, data reduction, data presentation, and concluding.

\section{Discussion}

Learning is a change in behavior (M. Ngalim) ${ }^{4}$ which is the process of actively changing behavior, the process of reacting to all situations that exist around the individual, the process directed at a goal, the process of acting through various experiences, the process of seeing, observing, and understand something that is learned. Learning is the process of interaction of students with educators and learning resources in a learning environment. Learning is the assistance given by educators so that the process of acquiring knowledge and knowledge, mastery of skills and character, as well as the formation of attitudes and beliefs in students. In other words, learning is a process to help students to learn well. And also learning is a process of conscious effort made by individuals for a change from not knowing to know, from not having an attitude to being right, from being unskilled to being skilled at doing something. Learning is not merely mapping the knowledge or information conveyed. But how to involve individuals actively make or revise the learning outcomes they receive into a personal experience that is beneficial to them. ${ }^{5}$

The learning process experienced throughout a human's life can apply wherever and whenever. Learning has a meaning similar to teaching, although it has a different connotation. In the context of education, the teacher teaches that students can learn and master the content of the lesson to achieve something determined objectives (cognitive aspects), can also affect changes in attitude (affective aspects), and skills (psychomotor aspects) of a student. Teaching gives the impression as the work of one party, namely the work of the teacher only. While learning also implies an interaction between the teacher and students.

If we see and feel the current learning, the interaction between students and teachers does occur but through cyberspace, virtual, or interactions occur using tools or technological devices such as computers, notebooks, and mobile phones. He can also use the distance learning application that is currently provided by the government for free or paid if that provides private parties. Distance learning or referred to as distance learning at this time is needed by all students ranging from elementary school to tertiary level, and this is not only happening in Indonesia, even almost all over the world carry out learning by E-learning. Situations and conditions may not be conducive, but learning activities and activities can be carried out anywhere. Especially now that there is a lot of technology equipment available that can support the activities

\footnotetext{
4. M. Ngalim P, Psikologi Pendidikan.1996. p.72

${ }^{5}$ Deni Hardianto. Majalah Ilmiah Pembelajaran. 2005. p.96.
} 
of all people doing anything and anytime, anywhere. So there is no longer limited by time and place.

Teaching can be interpreted by the act of learning by students and teaching by teachers. The two components cannot be separated in the process of teaching and learning activities (KBM). Teaching and learning activities are a unity of twodirectional activities. Learning activities are primary activities, while teaching is secondary activities that are intended for optimal activity.

It can be concluded that Learning is a conscious effort from the teacher to make students learn, that is, changes in behavior or behavior in students who learn, where changes are obtained with new abilities that apply in a relatively long time. But with the present situation, can learning using distance learning be said to be implemented optimally? And is there no change in behavior towards students or students after participating in learning activities remotely? And how are the learning outcomes achieved by students after participating in distance learning? This needs to be reviewed and reviewed in this article. After observing and analyzing in a few weeks of learning carried out the online attack by students, students or teachers as control many positive things are found even though this may not be valid enough to be concluded because of a very short time.

The implementation of learning by E-learning is also meant by the ministry of Education and Culture with the application of independent learning ${ }^{6}$ which before the pandemic COVID-19 was echoed by Nadiem Makarim as independent learning. Students are required to be technologically literate, to be creative, to have high motivation, to be able to make an innovation whose purpose is to prepare the future Milineal to be ready with the challenges of globalization.

Nadiem Makarim's dream is now realized by the presence of students and students who are almost $65 \%$ able to use or carry out virtual learning. Although the percentage of students using Online Learning is not very significant, at least it has shown that there is progress, development, and innovation in the education system in Indonesia by using this Online Learning. Indeed, many schools and universities previously used e-learning or online learning, but not all of them were able to use online learning, due to limited resources such as teachers who did not understand and understood the various online learning applications used in the process and teaching and learning activities in schools. In addition to the limitations of the internet network, the availability of smartphones or notebooks that not all students can have.

The implementation of distance learning is one of the applications of the Merdeka learning launched by the Ministry of Education and Culture, because independent learning does not pursue forced targets, learning takes time and process. On behalf of education, it has never diminished from various innovations, such as learning that is being experienced by our students by using an online system. All students need different things from the teacher, as now experienced by students who previously only attended online if there is homework that is not enough time is carried

${ }^{6}$ Kemendikbud RI. Empat Pokok Kebijakan \#Merdeka Belajar \#. 2019. 
out at school. But such learning innovations must eventually or must be done by students, because of the circumstances and causes or effects of COVID -19.

Learning Merdeka is not a given process, but a process that is driven. How to be able to move with a willingness to achieve goals and consistency is a top priority. Educational reform is very difficult to do, besides requiring a long time also requires stakeholder policies. Independent learning is a natural learning process independently experienced outside of school, such as at home.

Implementation Teaching and learning activities that are currently carried out using distance learning applications or learning have not yet reached maximum results. The author cannot explain in detail because they have not gotten the evaluation results from the relevant education offices and teachers who carry out distance learning. But randomly and randomly the author can conclude that the overall implementation of distance learning has been very significant, because of the control of parents and remote monitoring of the teachers.

Learning activities through online learning during the period of learning at home the first day, no doubt many obstacles for those who have never done it. This is according to observation and analysis in some schools, because of the limitations of mobile devices or media connected to the internet, and the lack of internet connections which simultaneously have to use such a large internet network. In Jakarta, almost 95\% of schools use online learning 7 , and certainly, there is a frenzy of teachers, students, and parents to prepare all of that, because of course the endemic of COVID-19 is not expected to spread so quickly so that the government and the community are not so ready to deal with it, and the government must quickly take precautionary measures so that no more victims are affected by this coronavirus, so this outbreak is considered to be a national disaster, even a worldwide disaster.

The implementation of online study and study policies established by the ministry of education and culture as a form of vigilance and prevention of the spread of the corona Virus (COVID-19) which is increasingly widespread in Indonesia. As a form of vigilance and prevention, all learning activities are carried out through distance learning in the form of online lectures, online model lectures or in the form of assignments at home $\left(\mathrm{Fat}^{8}\right.$

Not only teaching and learning activities were also disrupted, but the virus originating from the country of the bamboo curtain also caused the implementation of activities in schools and campuses that had originally been scheduled to be changed according to the planned schedule. Students, lecturers, and student organizations are prohibited from carrying out activities that involve a large number of people for 14 days. However, all teaching staff and education staff still have to be presently working on campus as usual. This step was taken to anticipate and prevent the spread of coronavirus in the school, campus and surrounding areas.

\footnotetext{
7 Prediction of author. 2020.

${ }^{8}$ Fathan talks about the handling of COVID-19. 2020
} 
News of the ferocity of COVID-19 made people feel anxious because of the very intense news coverage carried out by television and electronic media. However, some people are indifferent or care not to this virus and are not disciplined in following the government's direction to remain at home. Coronavirus events that shocked this world even referred to by some people as a world war against viruses. Moments like this teach about the meaning of humanity. True humanity transcends boundaries of people, be it ethnicity, race, religion or background. Hopefully, the world learns from this event, and this epidemic of COVID-19 can be quickly resolved.

\section{The Impacts caused by COVID-19 in Indonesia on Teaching and Learning Activities}

\section{Impact of COVID-19 for education in general}

The cause of COVID-19 does not only have an impact on the health and global economy. But it affects all sectors, especially in the education sector. Therefore, it is necessary to take anticipatory steps by each education unit at the regional level given the number of important agendas, such as national exams, and selection of higher education entrance.

The United Nations Educational, Scientific and Cultural Organization (UNESCO) notes, COVID-19 has an impact on the education of around 290.5 million students worldwide. UNESCO Director-General Audrey Azoulay said disadvantaged children and adolescents were those who tended to be most affected by the closure of schools. Although the temporary closure of schools as a result of health problems and other crises is not new, however, the current global scale and speed of educational disruption are unmatched and if extended, could threaten the right to education. ${ }^{9}$

As quoted from the official website of UNESCO, that UNESCO noted, until March 4, 2020, 22 countries had announced the closure of temporary schools to prevent the spread of COVID-19, previously, only China had implemented the policy. They revealed that nine countries had implemented school closures locally to prevent the spread of the coronavirus. If this is expanded into national policy, 180 million children and other young students will be affected. UNESCO states that while it is temporary, school closures have an impact on reduced teaching time and can have an impact on achievement. Also, other losses that will arise are the discomfort in the family and the decline in economic productivity because parents have to take care of children while working. Therefore, UNESCO supports the implementation of distance learning programs on a large scale and recommends applications and educational platforms that are useful and can be used by schools and teachers to reach students from a distance.

Central to local governments provide policies to dismiss all educational institutions. This is done as an effort to prevent the spread of Coronavirus transmission. This policy is expected with all educational institutions not carrying out activities, as usual, to minimize the spread of Co-19 diseases. The same thing has also

${ }^{9}$ UNESCO International Research and Training Centre for Rural Education. 2020. p.1. 
been done by various countries exposed to these Co-19 diseases. Lockdown or quarantine policy is done to reduce the interaction of many people who can give access to the spread of the Coronavirus. The spread of the Coronavirus was initially very influential in the world of the economy which is starting to be sluggish, but now the impact is also felt by the world of education. The policies are taken by many countries including Indonesia by dismissing all educational activities, making the government and related institutions must present alternative educational processes for students and students who cannot carry out the educational process in educational institutions. Based on data obtained from UNESCO, currently, there are a total of 39 countries have implemented school closures with the total number of students affected reaching $421,388,462$ children. China has by far the largest number of students affected by the coronavirus, which is around more than 233 million students. While other countries, until March 13, 2020, there were 61 countries in Africa, Asia, Europe, the Middle East, North America and South America that had announced or implemented restrictions on school learning to universities. UNESCO provides direct support to countries, including solutions for inclusive distance learning. ${ }^{10}$

Audrey Azoulay, 2020, in a statement emphasized, UNESCO together with each country worked together to ensure the continuity of learning for all, especially children and disadvantaged youth who tended to be hardest hit by school closures. The policy of closing schools in these countries has an impact on nearly 421.4 million children and adolescents in the world. Countries affected by COVID-19 place national responses in the form of learning platforms and other devices such as distance learning. The UNESCO website states that this Corona pandemic threatens 577 million students in the world. The total number of students who are potentially at risk from pre-primary to high school education is $577,305,660$. While the number of students who are potentially at risk from tertiary education is $86,034,287$ people. ${ }^{11}$

Currently in Indonesia, several campuses have begun implementing policies for teaching and learning activities from a distance or online learning. This is not a problem for universities that already have an online academic system. But it will be a problem for universities that do not yet have an academic system based online, especially if the resources of the teachers do not understand the learning system by using online applications. Not to mention the problem of the internet connection is not good on every campus or schools and not all students have smartphones and notebooks or computers connected to the internet. This is one of the obstacles faced by the government to implement online learning. The Ministry of Education and Culture is based on official information, ready with all scenarios including the application of working together to encourage online learning (in networks) for students. This is an effort to keep students studying at home, the Ministry of Education and Culture (Kemendikbud) prepares some support to expedite the process. The Ministry of Education and Culture itself develops distance learning applications based on the

${ }^{10}$ Huang, R.H., Liu, D.J., Tlili, A., Yang, J.F., Wang, H.H., et al. Handbook on Facilitating Flexible Learning During Educational Disruption: The Chinese Experience in Maintaining Undisrupted Learning in COVID-19 Outbreak. Beijing:2020. p.3

${ }^{11}$ Op.Cit 
portal and android Rumah Belajar. It's can be accessed at learning.kemdikbud.go.id. Some features Featured that can be accessed by students and teachers include Learning Resources, Digital Classes, Virtual Laboratories, and Question Banks. The Learning House can be used by students and teachers of Early Childhood Education (PAUD), Elementary Schools (SD), Junior High Schools (SMP), High Schools or Vocational Schools (SMA / SMK) and equivalent to be used free of charge.

The Ministry of Education and Culture has partnered with seven online learning platforms namely Smart Classes, Your School, Zenius, Quipper, Google Indonesia and Microsoft. Each platform will provide facilities that are publicly accessible and free. These online learning platforms can be accessed by students and teachers to increase learning resources.

The Corona pandemic is indeed a tough test for all nations, testing the ability of all nations to be able to take wisdom by continuing to strive and endeavor to find solutions to every problem that exists. As a big nation, Indonesia must be able to overcome all existing problems. This is proven by Indonesia being ready with all possibilities, with the birth of technologies created by the nation's children to provide online education services. With the hope that this nation will become a nation that is tested and deserves to be great in the future.

\section{Strategic Steps to Overcome the Impact of COVID-19 on Teaching and Learning Activities}

In Indonesia, Corona positive sufferers also continue to grow. With this increase in sufferers, it has had a greater negative effect on the education sector. To reduce the impact, strategic steps are needed. This needs to be done by the government quickly and precisely. The first thing to do is to provide education to students and education practitioners. This can be done with intensive socialization by the health department about the Coronavirus itself, both from the aspect of prevention and how to react. With this insight, it is expected to reduce the effects of excessive worry which can have a traumatic impact on students and of course their teachers. The second step is the need to prepare a special team of psychologists to assist students both collectively and individually, especially for schools in areas affected by the virus. Like the DKI area which has the most Coronaviruses detected. Students affected by COVID19 but declared cured are expected to be able to assist to ease their psychological burdens as well as reinforce their enthusiasm for learning.

As for the obstruction of the educational process due to closure and delay in study time, it is necessary to prepare concrete solutions as well. One thing that can be done is the distance learning system by utilizing existing technology. Because if not, then this will hurt the development of the maturity of the results and achievement of the education process. (Muhammad Rajab) ${ }^{12}$.

12 Muhammad Rajab. Opini. Revitalisasi Peran dan Fungsi Guru. https://www.harianbhirawa.co.iScho. 


\section{Indonesian Ministry of Education and Culture's Policy Against Corona Virus outbreaks in Teaching and Learning Activities (KBM)}

The school is a place of interaction and teaching and learning in the classroom. There where students get knowledge. The learning process will be more successful if the learning material is packaged so well that it can attract the attention of all students. So far the school is a second home for students, where the teacher is the second parent for all students. ${ }^{13}$ The school is an institution that we know is a clean, environmentally friendly and comfortable place for all students. But who would have thought the school which was once a second home for students, a comfortable place but now considered unsafe for all school residents? This is due to the Coronavirus which is increasingly spreading.

Minister of Education and Culture (Mendikbud) Nadiem Anwar Makarim supports the policy of the regional government (Pemda) which dismiss schools and postpones the implementation of the National Examination (UN). That was as a step to prevent the spread of Coronavirus or Coronavirus disease 2019 (COVID-19). The impact of the spread of COVID-19 will differ from one region to another. The Ministry of Education and Culture is ready to support the policies adopted by the Regional Government. The safety and safety of students and teachers and education personnel are the main ones. ${ }^{14}$ The policy of the central government which supports local governments to lay off students for the next few days to study at home is welcomed by the local government, for example, the DKI-Jakarta government applies to learn at home at all levels starting from elementary and junior high, high school. Even before the official application of learning at home was officially established, several university campuses had implemented E-Learning or Online learning. Although learning activities are not carried out face-to-face in the classroom, it is hoped that all students and students can study independently at home online, so as long as they are laid off all students or students do not miss lessons.

The Ministry of Education and Culture urges each education unit to report to the education office, health office or Higher Education Service Institution in the event of a mass absence of students. Then consult with the education office or LL Dikti if the absence rate interferes with the teaching and learning process, so a solution will be sought. In a circular, the Ministry of Education and Culture explains the mechanism for students and parents of students traveling in affected countries, then asked to take a break for the next few days. Students are obliged to monitor their health at home at any time, but also actively detect their health, both to the doctor or to the health care center. So, not only at home but actively check health.

To anticipate the spread of CoronaVirus in all schools, it is suggested to activate the role of School Health Enterprises (UKS) or health service units in tertiary institutions by coordinating with local health service facilities to prevent the spread of

${ }^{13}$ Yuli Hendarti, Optimalisasi Pembelajaran Berbasis Online Selama COVID-19

ttps://www.rakyatpos.com/optimalisasi. (searching, 22 Maret 2020).

${ }^{14}$ https://kompas.id/baca/riset/ (seen on 20 /03/ 2020. 
COVID-19. Small businesses that can be done by schools are to improve the cleanliness of the school environment, all school residents wash their hands more often, do not contact directly with fellow students such as shaking hands, hugging, and others. If there is an indication that the COVID-19 Virus is infected, immediately communicate with the Health Officer, the Education Office and or the Higher Education Service Institution to find out whether the Health Office has some kind of plan or preparation in dealing with COVID-19. Besides addition, the school must also ensure the availability of facilities for handwashing with soap (CTPS) and disposable cleaning tools (wipes) in various strategic locations in the education unit. Also, ensure that education unit residents use CTPS advice (minimum of 20 seconds) and disposable hand dryers as they should, and other healthy clean living (PHBS) behaviors must be consistently implemented. ${ }^{15}$

If we look at technological advances in the present, learning is not only done in the classroom, it can also be done online. Teachers as educators must be wise in taking the right steps to continue learning even if it is not carried out in the classroom. This is given the current situation in the country that is being hit by the COVID-19 Virus. According to Law Number 14 of $2005^{16}$ Concerning teachers and lecturers, in carrying out their profession, teachers are required to improve and develop academic qualifications and competencies in a sustainable manner in line with the development of science and technology, teachers must be able to present a memorable and meaningful learning atmosphere. In the ideal level, the teacher can work together in developing teaching materials into online learning media that are following the characteristics of students. The development of interesting teaching materials becomes a demand that the learning process does not take place boring. In this case, the creativity and innovation of the teacher communicating the material communicatively determine the success of online learning. By utilizing an online learning system, it is possible to package teaching materials in an interactive digital format.

The use of online learning systems in the educational dimension is inevitable. The fact is, not a few students who spend hours with their gadgets, for laptops, tablet PCs, or their smartphones. By accessing the internet, they can search for various information and knowledge they want or just show their existence through social media. This phenomenon is both a challenge and an opportunity for teachers to be creative in developing learning methods that are interesting, innovative and fun. Innovative learning that utilizes an online basis as a medium can be realized in the form of interactive multimedia-based learning and personal blog-based learning media by teachers. The learning process is not merely insulated by space and time. Science is not only absolute can be obtained orally through a teacher, but can also be obtained through various references such as the internet. On the other hand, the teaching style of the teacher also experienced a transformation from conventional lecture models to multimedia-based presentations. Especially in the 2013 curriculum requires teachers to

${ }^{15}$ Loc.cit

${ }^{16}$ Law Number 59 based on Law Number 6 the Year 2018 concerning Health Quarantine. 
massively master ICTs to support the learning process. According to (Reeves, 1998), in the learning process, there are two main approaches in the use of ICT, namely students can learn 'from' and 'with' ICT. Learning 'from' ICT is done. As in the use of computerbased instruction (tutorials) or integrated learning systems. Whereas learning 'with' ICT is to use it as cognitive tools and constructivist learning environments.

By using an online learning system, ideally, it can change the face of education in a direction that is better, more enjoyable, and more effective for students. Based on the condition of our country that is currently being hit by the COVID-19 Virus, the role of online-based learning as a support to the learning process becomes very significant and necessary. Especially in the current global era, transformation is going very fast. The reality is students can even more easily adapt to new technologies and changes that exist today. The application of online-based learning to teaching and learning has two major challenges, namely: (1) the application of online-based learning as 'difficult alternatives for students'; and (2) online-based application to produce knowledgeable students (knowledge-based student), which is to take advantage of online-based to develop themselves continuously (long life learning) and increase their productivity.

Online-based learning is expected to have a positive impact on students and the progress of our education. In this case, the teacher also expects the participation and care of parents at home to encourage their children to study at home, using onlinebased learning facilities and systems that have been established by the government through the Education Office during COVID-19.

\section{Conclusion}

Pandemic Coronavirus that can attack human breathing, this virus is very dangerous and until now there has not been found a drug or faction. As for the other countries that are worse after China, Italy, Iran, South Korea, Britain, Germany, and other countries including Indonesia. The most effective anticipation to reduce this Coronavirus is to avoid the crowds (stay at home), maintain cleanliness and maintain endurance. The impact experienced by each country is in the economic, socio-cultural fields, and not least in the fields of education, school, campus, all are closed and replaced by learning from home by using online or called E-learning. Learning using Elearning brings progress and innovation to education in Indonesia because almost 75\% of students conduct online learning simultaneously during the COVID-19 epidemic. Obstacles to implementing this E-Learning certainly exist, for example, internet networks are not met, students are not used to, teachers, and even parents as a companion studying at home to do online learning. This is certainly a normal thing because it has not become a habit for students and teachers to implement KBM in the future, a process that requires better learning outcomes.

Various attempts were made to tackle the pandemic, including by limiting interactions between community members. Restricting activities include: a consolation of schools and workplaces, restrictions on religious activities, and restrictions on 
activities in large-scale social and public facilities are part of emergency response and aim to prevent the spread of the disease.

The occurrence of this event is a lot of wisdom that can be learned, one of which is that we have not paid attention to our environment, lack of cleanliness, far from religious orders that we should practice in our daily lives, away from family and we are more concerned with things - worldly things. This has become a rebuke from the Almighty to humanity in this world.

\section{Reference}

Buku:

Handbook of facilitating flexible learning during education disruptions. UNESCO International Research and Training Centre for Rural Education. The Chinese experience in maintaining disruptions learning in the COVID-19 outbreak .2020.

Hardianto, Deni. Majalah Ilmiah Pembelajaran. Vol. 1 Jakarta. 2005.

Huang, R.H., Liu, D.J., Tlili, A., Yang, J.F., Wang, H.H., et al. Handbook on Facilitating Flexible Learning During Educational Disruption: The Chinese Experience in Maintaining Undisrupted Learning in COVID-19 Outbreak. Beijing: Smart Learning Institute of Beijing Normal University.2020.

Kennedy, Paul, Menyiapkan Diri menghadapi Abad ke-21. Yayasan Obor: Jakarta. 1995.

P, M. Ngalim. Psikologi Pendidikan. Bandung. Penerbit.Remaja Rosda Karya. ISBN 979514-036-1. Edisi pertama. cetakan ke. XXVII. 1997.

Purwadinata, 1967, Psikologi Pendidikan dengan Pendidikan Baru. PT Remaja Rosdakarya: Bandung. 1997.

Suparno, Paul. Teori Perkembangan Kognitif Jean Piaget. Yogyakarta: Penerbit Kanisius. Solso. 1991.

Suparno, Paul. Teori Perkembangan Kognitif. Public. Kanisius, Jakarta. .1997.

\section{Media on-Line.}

Audrey Azoulay, UNESCO. Dirjen UNESCO Director-General of the United Nations Educational, Scientific and Cultural Organization (UNESCO) seen on 22 Maret 2020.

Dedy Afrianto, Seminar antisipasi Dampak Covid-19 di Sektor PendidikanPandemi Covid-19 yang disebabkan virus korona baru memberikan dampak pada sektor pendidikan. 2020.

Fathan, Anggota komisi V. DPR RI, berbicara masalah penangulangan Covid-19. (Dilihat 20 MARET 2020. 
Haryono. 2017. Teknologi Pendidikan dan Pembelajaran Abad 21. Makalah Seminar Nasional Teknologi Pendidikan dengan Tema "Inovasi Pendidikan di Era Cyber dan Peran Teknologi Pendidikan/Pembelajarann dalam Meningkatkan Mutu Pendidikan di Indonesia" di Banjarmasin. Pascasarjana Universitas Negeri Semarang. Ristekdikti. 2018. Mempersiapkan SDM Indonesia di Era Revolusi Industri 4.0. Kementerian Riset, Teknologi dan Pendidikan Tinggi.

Hendarti, Yuli. Guru SMA Negeri 1 Pemali, Kab. Bangka, Bangka BelitungMedia online.

Hendarti, Yuli. Optimalisasi Pembelajaran Berbasis Online Selama Covid-19 https://www.rakyatpos.com/optimalisasi. (searching, 22 Maret 2020).

https://aceh.tribunnews.com/2020/03/21/pengaruh-corona-terhadap-kehidupan-sosialmasyarakat.

https://anteroaceh.com/news/corona-dan-dampak-sosial/index.html.

https://kompas.id/baca/riset/ (dilihat pada tanggal 20 /03/ 2020.

https://www.rakyatpos.com/dampak-penyebaran-virus-corona-terhadappembelajaran-di-sekolah.html/

Lestari Dewi, (13 “Teori-teori Belajar dan Pembelajaran", http://biologilestari.blogspot.co.id

M Razi Rahman,https://today.line.me/i ntaranews.com dilihat 20 maret 2020.

Muhammad Rajab Director of Ma'had and Islamic Studies Tazkia International Islamic Boarding School, Malang. Seminar, 2020.

Nadiem makarim. (Kompasiana, 2020). 15/03/2020). Dilihat 21- maret 2020.

Prayanto, Yugi. Dalam acara Outlook Perikanan 2020 di Jakarta, Rabu (26/2. 2020. (seen on 22 Maret 2020.)

Sapto Waluyo (Center for Indonesian Reform) https://www.suara.com/

serambinews.com dengan judul Pengaruh Corona terhadap Kehidupan Sosial Masyarakat,

Teori Pembelajaran", (13 september 2016) http://joegolan.wordpress.co.id

Uffie, Direktur kelas Pinter, aplikasi pembelajaran -e -Learning. 2020.

Undang-Undang Nomor 59 berdasarkan Undang-undang Nomor 6 Tahun 2018 tentang Kekarantinaan Kesehatan

Website Pemda DKI : $\underline{\text { http://corona.jakarta.go.id. }}$ 
Zaharah, Galia Ildusovna Kirilova, Anissa Windarti

282- Fakultas Syariah dan Hukum UIN Syarif Hidayatullah Jakarta 


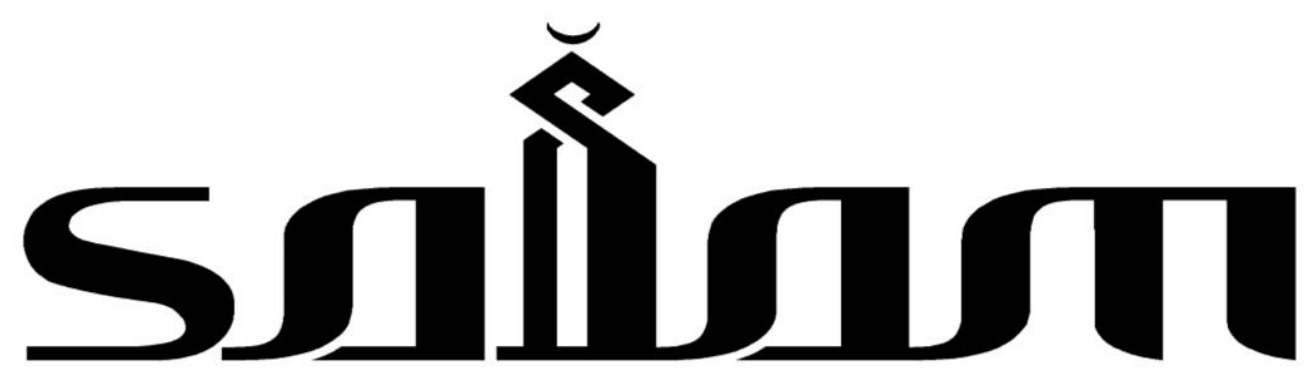

Jumnal Sosial dan Budaya Syar'i

\section{PEDOMAN TEKNIS PENULISAN BERKALA ILMIAH}

1. Artikel adalah benar-benar karya asli penulis, tidak mengandung unsur plagiasi, dan belum pernah dipublikasikan dan/atau sedang dalam proses publikasi pada media lain yang dinyatakan dengan surat pernyataan yang ditandatangani di atas meterai Rp 6000;

2. Naskah dapat berupa konseptual, resume hasil penelitian, atau pemikiran tokoh;

3. Naskah dapat berbahasa Indonesia, Inggris, Arab, maupun bahasa Rusia;

4. Naskah harus memuat informasi keilmuan dalam ranah ilmu hukum Positif;

5. Aturan penulisan adalah sebagai berikut:

a. Judul. Ditulis dengan huruf kapital, maksimum 12 kata diposisikan di tengah (centered);

b. Nama penulis. Ditulis utuh, tanpa gelar, disertai afiliasi kelembagaan dengan alamat lengkap, dan alamat e-mail;

c. Abstrak. Ditulis dalam bahasa Inggris dan Bahasa Indonesia antara 80-120 kata;

d. Sistematika penulisan naskah adalah sebagai berikut:

1) Judul;

2) Nama penulis (tanpa gelar akademik), nama dan alamat afiliasi penulis, dan e-mail;

3) Abstrak ditulis dalam dua bahasa, yaitu bahasa Indonesia dan Inggris, antara 80-120 kata;

4) Kata-kata kunci, antara 2-5 konsep yang mencerminkan substansi artikel;

5) Pendahuluan;

6) Sub judul (sesuai dengan keperluan pembahasan);

7) Penutup; dan

8) Pustaka Acuan (hanya memuat sumber-sumber yang dirujuk dan sedapat mungkin terbitan 10 tahun terakhir).

e. Ukuran kertas yang digunakan adalah kertas HVS 70 gram, ukuran A4, margin: atas $3,5 \mathrm{~cm}$, bawah $3.5 \mathrm{~cm}$, kiri $3,5 \mathrm{~cm}$, dan kanan $3,5 \mathrm{~cm}$;

f. Panjang Naskah antara 13 s.d. 15 halaman, spasi 1, huruf Palatino, ukuran 11;

g. Pengutipan kalimat. Kutipan kalimat ditulis secara langsung apabila lebih dari empat baris dipisahkan dari teks dengan jarak satu spasi dengan ukuran huruf 10 point. Sedangkan kutipan kurang dari empat baris diintegrasikan dalam teks, dengan tanda apostrof ganda di awal dan di akhir kutipan. Setiap kutipan diberi nomor. Sistem pengutipan adalah footnote (bukan bodynote atau endnote). Penulisan footnote menggunakan sistem turabian. Setiap artikel, buku, dan sumber lainnya yang dikutip harus tercantum dalam pustaka acuan;

h. Pengutipan Ayat Alquran dan Hadis. Ayat yang dikutip menyertakan keterangan ayat dalam kurung, dengan menyebut nama surah, nomor surah, dan nomor ayat, seperti (Q.s. al-Mu'min [40]: 43). Pengutipan Hadis menyebutkan nama perawi (H.r. al-Bukhārĩ dan Muslim) ditambah referensi versi cetak kitab Hadis yang dikutip. Hadis harus dikutip dari kitab-kitab Hadis standar (Kutub al-Tis'ah);

i. Cara pembuatan footnote. Footnote ditulis dengan font Palation size 9, untuk pelbagai sumber, antara lain: 
1) Buku: nama utuh penulis (tanpa gelar), judul buku (tempat terbit: penerbit, tahun terbit), cetakan, volume, juz, halaman. Contoh: Soerjono Soekanto, Pokok-pokok Sosiologi Hukum, (Jakarta: Rajawali Pers, 1986), h. 10.

2) Buku terjemahan, contoh: Roscoe Pound, Pengantar Filsafat Hukum: Buku III, diterjemahkan oleh Moh. Radjab, (Jakarta: Bharata, 1963), h. 15;

1) Jurnal, contoh: Nur Rohim, "Kontroversi Pembentukan Perppu No. 1 Tahun 2013 tentang mahkamah konstitusi dalam ranah kegentingan yang memaksa", dalam Jurnal Cita Hukum, Vol. 2, No. 1 (2014), h. 157.

2) Artikel sebagai bagian dari buku (antologi), contoh: Hikmahanto Juwana, "Penegakan Hukum dalam Kajian Law and Development: Problem dan Fundamen bagi Solusi Indonesia", dalam Muhammad Tahir Azhary, Beberapa Aspek Hukum Tata Negara, Hukum Pidana, dan Hukum Islam, (Jakarta: Kencana Prenada Media Gorup, 2012), h. 127.

3) Artikel dari internet, contoh: Ahmad Tholabi Kharlie, "Problem Yuridis RUU Syariah" dalam http://ahmadtholabi.com/2008/03/03/problem-yuridis-ruu-syariah, diunduh pada 20 Maret 2012.

4) Artikel dari majalah, contoh: Susilaningtias, "Potret Hukum Adat pada Masa Kolonial", dalam Forum Keadilan, No. 17, 20 Agustus 2006.

5) Makalah dalam seminar, contoh: Jimly Asshiddiqie, "Kedudukan Mahkamah Konstitusi dalam Struktur Ketatanegaraan Indonesia", Makalah disampaikan dalam Kuliah Umum Fakultas Hukum Universitas Sebelas Maret, Surakarta, pada 2 Maret 2004.

j. Pustaka Acuan: daftar pustaka acuan ditulis sesuai urutan abjad, nama akhir penulis diletakkan di depan. Contoh:

1) Buku, contoh: Soekanto, Soerjono, Pokok-pokok Sosiologi Hukum, Jakarta: Rajawali Pers, 1986.

2) Buku terjemahan, contoh: Pound, Roscoe, Pengantar Filsafat Hukum: Buku III, diterjemahakan oleh Moh. Radjab, Jakarta: Bharata, 1963.

3) Jurnal, contoh: Rohim, Nur, "Kontroversi Pembentukan Perppu No. 1 Tahun 2013 tentang mahkamah konstitusi dalam ranah kegentingan yang memaksa", dalam Jurnal Cita Hukum, Vol. 2, No. 1 (2014).

4) Artikel sebagai bagian dari buku, contoh: Juwana, Hikmahanto, "Penegakan Hukum dalam Kajian Law and Development: Problem dan Fundamen bagi Solusi Indonesia", dalam Muhammad Tahir Azhary, Beberapa Aspek Hukum Tata Negara, Hukum Pidana, dan Hukum Islam, Jakarta: Kencana Prenada Media Gorup, 2012.

5) Artikel yang dikutip dari internet, contoh: Kharlie, Ahmad Tholabi, "Problem Yuridis RUU Syariah" dalam http://ahmadtholabi.com/2008/03/03/problem-yuridis-ruu-syariah, diunduh pada 20 Maret 2012.

6) Majalah, contoh: Susilaningtias, "Potret Hukum Adat pada Masa Kolonial", dalam Forum Keadilan, No. 17, 20 Agustus 2006.

7) Makalah dalam seminar, contoh: Asshiddiqie, Jimly, "Kedudukan Mahkamah Konstitusi dalam Struktur Ketatanegaraan Indonesia", Makalah disampaikan dalam Kuliah Umum Fakultas Hukum Universitas Sebelas Maret, Surakarta, pada 2 Maret 2004.

k. Penutup: artikel ditutup dengan kesimpulan;

I. Biografi singkat: biografi penulis mengandung unsur nama (lengkap dengan gelar akademik), tempat tugas, riwayat pendidikan formal (S1, S2, S3), dan bidang keahlian akademik;

6. Setiap naskah yang tidak mengindahkan pedoman penulisan ini akan dikembalikan kepada penulisnya untuk diperbaiki.

7. Naskah sudah diserahkan kepada penyunting, selambat-lambatnya tiga bulan sebelum waktu penerbitan (April, Agustus. dan Desember) dengan mengupload pada laman OJS jurnal pada alamat http://journal.uinjkt.ac.id/index.php/salam atau dikirim langsung via e-mail ke: jurnal.salam@gmail.com atau nurrohimyunus@uinjkt.ac.id..] 


\section{Indexed by :}
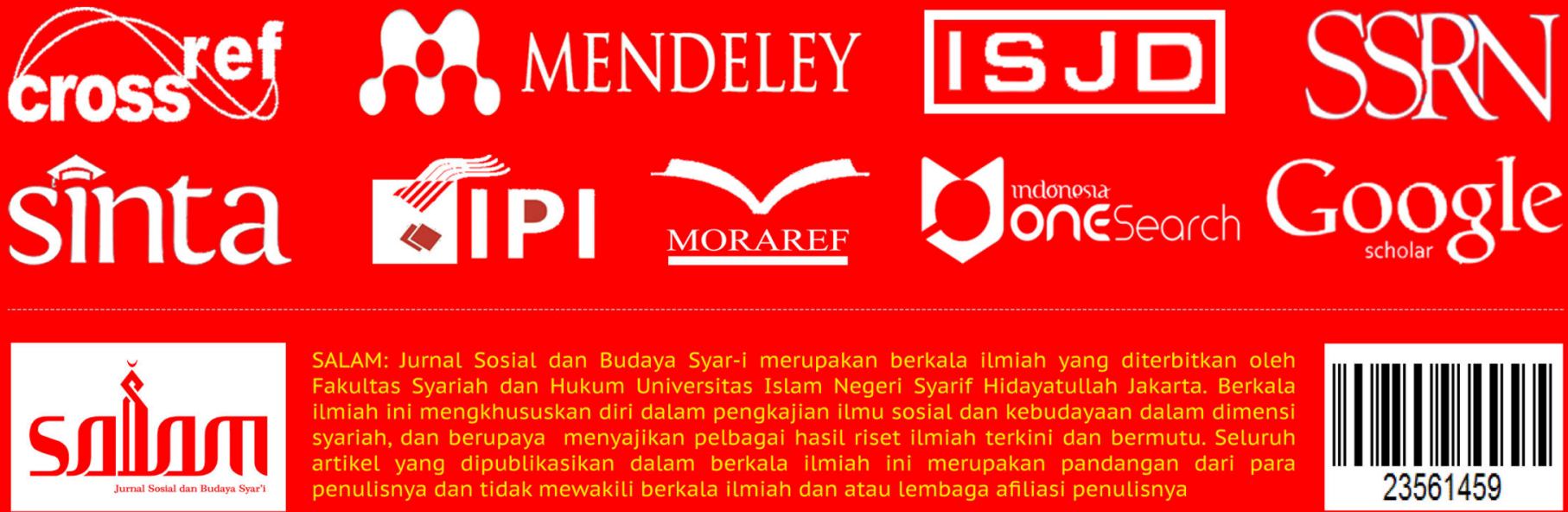

SALAM: Jurnal Sosial dan Budaya Syar-i merupakan berkala ilmiah yang diterbitkan oleh Fakultas Syariah dan Hukum Universitas Islam Negeri Syarif Hidayatullah Jakarta. Berkala ilmiah ini mengkhususkan diri dalam pengkajian ilmu sosial dan kebudayaan dalam dimensi syariah, dan berupaya menyajikan pelbagai hasil riset ilmiah terkini dan bermutu. Seluruh artikel yang dipublikasikan dalam berkala ilmiah ini merupakan pandangan dari para penulisnya dan tidak mewakili berkala ilmiah dan atau lembaga afiliasi penulisnya

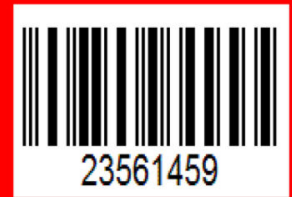

